\title{
Distribution of diatoms and silicoflagellates in surface sediments of the Yellow Sea and offshore from the Changjiang River, China*
}

\author{
WANG Yanna (王艳娜) $)^{1,2}$, LIU Dongyan (刘东艳) ${ }^{1, * *}$, DI Baoping (邸宝平) ${ }^{1}$, \\ SHI Yajun (石雅君) $)^{1}$, WANG Yujue (王玉珏) ${ }^{1}$ \\ ${ }^{1}$ Key Laboratory of Coastal Zone Environmental Processes and Ecological Remediation, Yantai Institute of Coastal Zone \\ Research, Chinese Academy of Sciences, Yantai 264003, China \\ ${ }^{2}$ University of Chinese Academy of Sciences, Beijing 100049, China
}

Received Sep. 25, 2014; accepted in principle Oct. 21, 2014; accepted for publication Feb. 14, 2015

(C) Chinese Society for Oceanology and Limnology, Science Press, and Springer-Verlag Berlin Heidelberg 2016

\begin{abstract}
The spatial distribution of siliceous microfossils (diatoms and silicoflagellates) in the surface sediments was mapped at 113 sites in the Yellow Sea and sea areas adjacent to the Changjiang (Yangtze) River, China. In total, 267 diatom taxa and two silicoflagellate species were identified from the sediments. The spatial variations in abundance and diversity were classified into three distinct geographic patterns using Q mode clustering: a south-north geographic pattern, a coastal-offshore pattern and a unique pattern in the Changjiang River mouth. The south-north geographic pattern was related to the spatial variations in sea temperature. Coscinodiscus oculatus, a warm-water species, indicated these variations by a gradual decrease in abundance from the south to the north. The coastal-offshore pattern was in response to the spatial variations in salinity. Cyclotella stylorum, Actinocyclus ehrenbergii and Dictyocha messanensis, the dominant brackish species in coastal waters, significantly decreased at the isobaths of approximately $30 \mathrm{~m}$, where the salinity was higher than 31. Paralia sulcata and Podosira stelliger indicated the impact of the Yellow Sea Warm Current in the central Yellow Sea. The unique pattern in the Changjiang River mouth showed the highest species diversity but lower abundance, apparently because: freshwater input can significantly increase the proportion of brackish species; nutrients can supply the growth of phytoplankton; and high sedimentation rates can dilute the microfossil abundance in the sediments. Our results show that an integration of environmental factors (e.g., nutrient levels, sedimentation rate, sea temperature, salinity and water depth) determined the spatial characteristics of the siliceous microfossils in the surface sediments.
\end{abstract}

Keyword: siliceous microfossil; Yellow Sea; Changjiang (Yangtze) River; biogeography; sedimentary environment

\section{INTRODUCTION}

Diatoms are a major phytoplankton group with a wide distribution and high abundance in most aquatic ecosystems. In contrast, silicoflagellates are a relatively smaller group in the phytoplankton assemblages, and contribute less to primary production (Dawes, 1998). Both diatoms and silicoflagellates are widely used for reconstructing and interpreting environmental conditions, because their abundances and species compositions are sensitive to varied living environmental conditions (e.g., temperature, salinity and eutrophication). In addition, their cell walls or siliceous skeletons can remain in sediments and are distinct enough to allow accurate species identification and enumeration after millions of years of preservation (Battarbee et al., 2001; Berglund et al., 2005; Weckström, 2006; Smol and Stoermer, 2010). For example, Berglund et al.

\footnotetext{
* Supported by the National Natural Science Foundation of China (No. 41376121), the Strategic Priority Research Program of Chinese Academy of Sciences (No. XDA11020405), the Natural Science Foundation of Shandong Province (No. JQ201414), and the Cooperation Project of Chinese Academy of Sciences and Hebei Academy of Sciences (No. 13001001)

** Corresponding author: dyliu@yic.ac.cn
} 


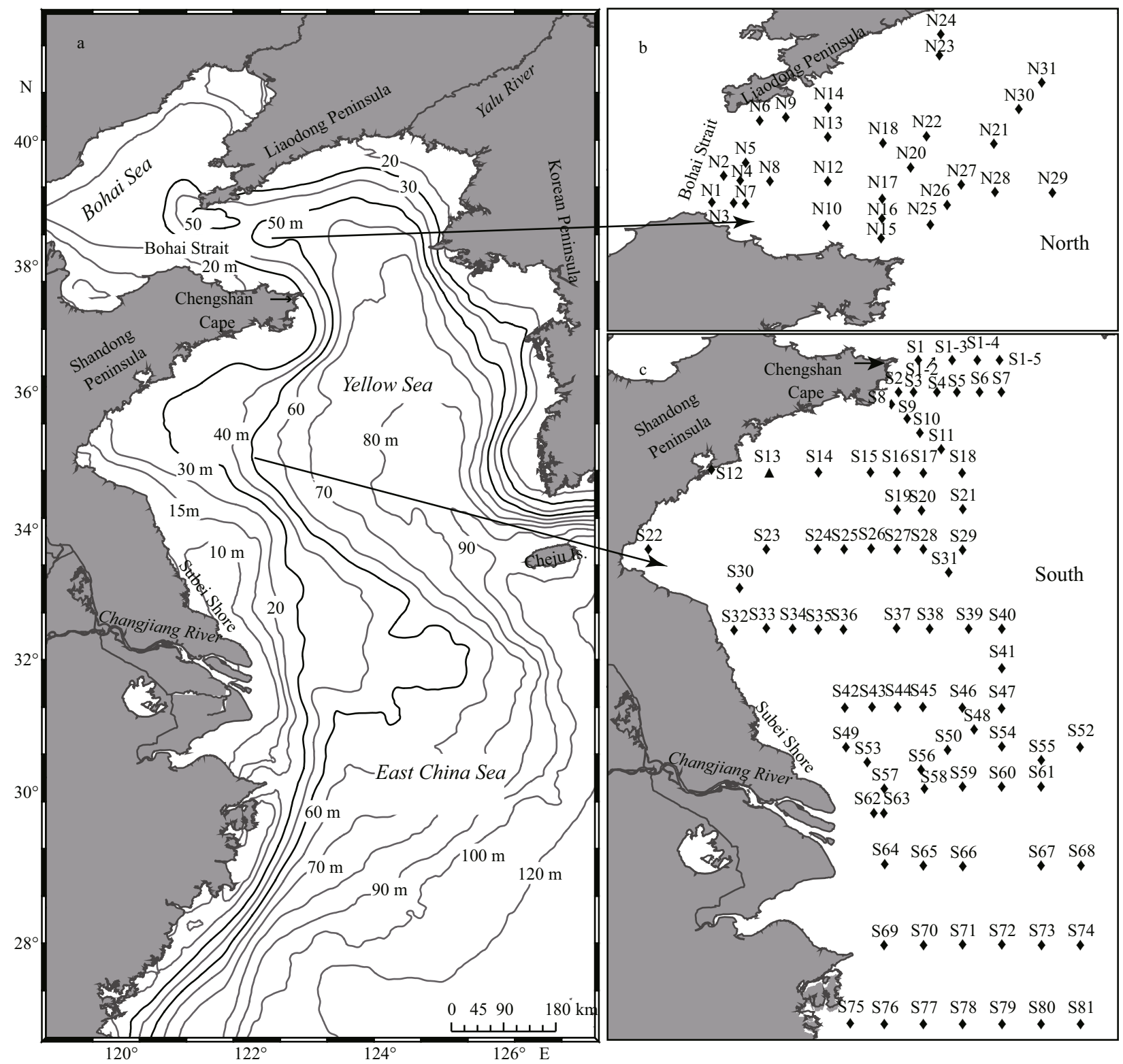

Fig.1 Study area with bathymetric features and sampling sites

a. map of the Yellow Sea; b. sampling sites in the northern Yellow Sea; c. sampling sites in the southern Yellow Sea and offshore from Changjiang River.

(2005) traced the coastal evolution of Blekinge, Sweden by the variations in the proportions of marine, brackish and freshwater diatom microfossils. Weckström (2006) used the records of diatom microfossils to assess the recent eutrophication in the Baltic Sea, and linked it to an increase in nitrogen loading.

Previous studies also found that a series of biological, chemical and physical factors-water depth, temperature, salinity, current, grain size, microfossil dissolution, sedimentation rate, grazing pressure, and aggregation - can impact or jointly determine the distribution of siliceous microfossils in sediments (Yamada and D'Elia, 1984; Battarbee et al., 2001; Smol and Stoermer, 2010). These disturbances can influence the accuracy of environmental reconstruction or data interpretation. Therefore, it is necessary to map the spatial distribution of microfossils in the surface sediments and to identify the key environmental factors that impact their abundance and species composition in a specific region, before interpreting deep-core samples.

The Yellow Sea (YS) is a semi-enclosed marginal sea surrounded by mainland China and the Korean peninsula, with an approximate area of $380000 \mathrm{~km}^{2}$ (Fig.1a). In coastal waters, the YS is characterized by 
lower salinity $(<31)$ and higher nutrient and chlorophyll $a$ concentrations because of the amount of freshwater input from rivers. In offshore waters, the YS displays higher salinity $(>31-33)$ and lower nutrient and chlorophyll $a$ concentrations because of the intrusion of the Kuroshio Current and East China Sea. The maximum sea surface temperature (SST) in the southern YS can be $3-5^{\circ} \mathrm{C}$ higher than in the northern YS in most months because of the supply of warm water from the Kuroshio Current and the latitudinal variation in solar radiation (Lee and Chao, 2003).

Phytoplankton assemblages vary spatially with environmental change in the YS. For example, species composition in offshore waters displays a correlation to Yellow Sea Warm Current (YSWC) with an increase of warm-water and oceanic species. However, in coastal waters, brackish and temperate species are dominant in phytoplankton assemblages ( $\mathrm{Yu}$ and $\mathrm{Li}$, 1993; Du and Liu, 2009). The data provided by multitube sediment traps in 2002 showed that diatom cells and silicoflagellate skeletons were the dominant components in the settling matters in the YS (Guo et al., 2010). Wang et al. (1985) and Jiang (1987) analyzed diatom microfossils in the YS surface sediments at 24 sites and found that the spatial distribution of diatom assemblages followed a salinity gradient $(<30.0,31.0-32.5$ and $>32.0)$, responding to water depth $(<30 \mathrm{~m}, 30-50 \mathrm{~m}$ and $>50 \mathrm{~m})$ variation. However, because of the limited number of sampling sites (24), these previous studies were unable to give a full picture of the spatial distribution of siliceous microfossils in the YS.

In this study, 113 sampling sites were chosen to analyze the spatial distribution of siliceous microfossils (diatoms and silicoflagellates) in surface sediments. The sampling sites covered the entire YS from offshore of the Changjiang (Yangtze) River in the south to the Bohai Strait in the north (Fig.1b, c). This study had two goals: 1) to map the geographical distribution of siliceous microfossils and characterize their indicative roles in the whole YS, and 2) to explore the key environmental factors determining the spatial pattern of these microfossils. The species composition and the abundance of diatoms and silicoflagellates in the surface sediment were analyzed, and their assemblages were mapped and classified based on the Q mode clustering. Based on the survey environmental data, the correlations between siliceous microfossils and related environmental factors (e.g., water depth, grain size of sediment, sedimentation rate, temperature, salinity and nutrient) were examined to discern the indicative roles of microfossils.

\section{STUDY AREA}

The Yellow Sea is characterized by a typical temperate climatic regime, where the SST can drop below $5^{\circ} \mathrm{C}$ in winter and increase to $27^{\circ} \mathrm{C}$ in summer (Lee and Chao, 2003). The YS extends south from the Bohai Strait and is divided from the East China Sea in the south by an arbitrary line drawn between the Changjiang River mouth and Korea's Cheju Island. The YS water depth is generally less than $20 \mathrm{~m}$ in the western coastal region and deeper than $90 \mathrm{~m}$ in the eastern open sea near Cheju Island (Fig.1a). The hydrodynamic process in the YS is strongly controlled by the YSWC and coastal currents (Fig.2a). In winter, the YSWC incursion, driven onto the shelf by a branch of the Kuroshio Current, enters into the YS (Fig.2a) with warm, saline characteristics (Su, 1998). The strong and cold northwesterly winds can rapidly decrease the SST in the YS and drive coastal waters southward, which forms the Yellow Sea Coastal Current (YSCC) as a compensating effect (Fig.2a) (Su, 1998; Naimie et al., 2001). In summer, the YSWC becomes weaker, while a cold remnant of winter cooling and vertical mixing named the Yellow Sea Cold Water mass (YSCW) is maintained in the deeper depths of the central YS (Fig.2b) (Naimie et al., 2001).

Nearly 30 rivers empty a total of approximately $71 \times 10^{9} \mathrm{~m}^{3} / \mathrm{a}$ (cubic meters per annum) freshwater into the YS, resulting in coastal waters with low salinity and high nutrient concentrations. The Yalu River has the largest runoff: $37.9 \times 10^{9} \mathrm{~m}^{3}$ annually into the northern YS (Fig.2a) (Liu et al., 2003). In the southern YS, the Changjiang River contributes $130 \times 10^{9} \mathrm{~m}^{3}$ per year, which accounts for $14.1 \%$ of the Changjiang annual discharge (Riedlinger and Preller, 1995). Consequently, the YS salinity usually varies from 29 to 31 in coastal waters but reaches $31-33.5$ in offshore waters (Lee and Chao, 2003).

\section{MATERIAL AND METHOD}

\subsection{Sampling method}

Surface sediment box cores $\left(0.1 \mathrm{~m}^{2}\right)$ were taken at 113 sites during a cruise in October-November 2010 (Fig.1b, c). The top $2 \mathrm{~cm}$ of sediments were sliced and frozen for laboratory analysis. The surface sediment 

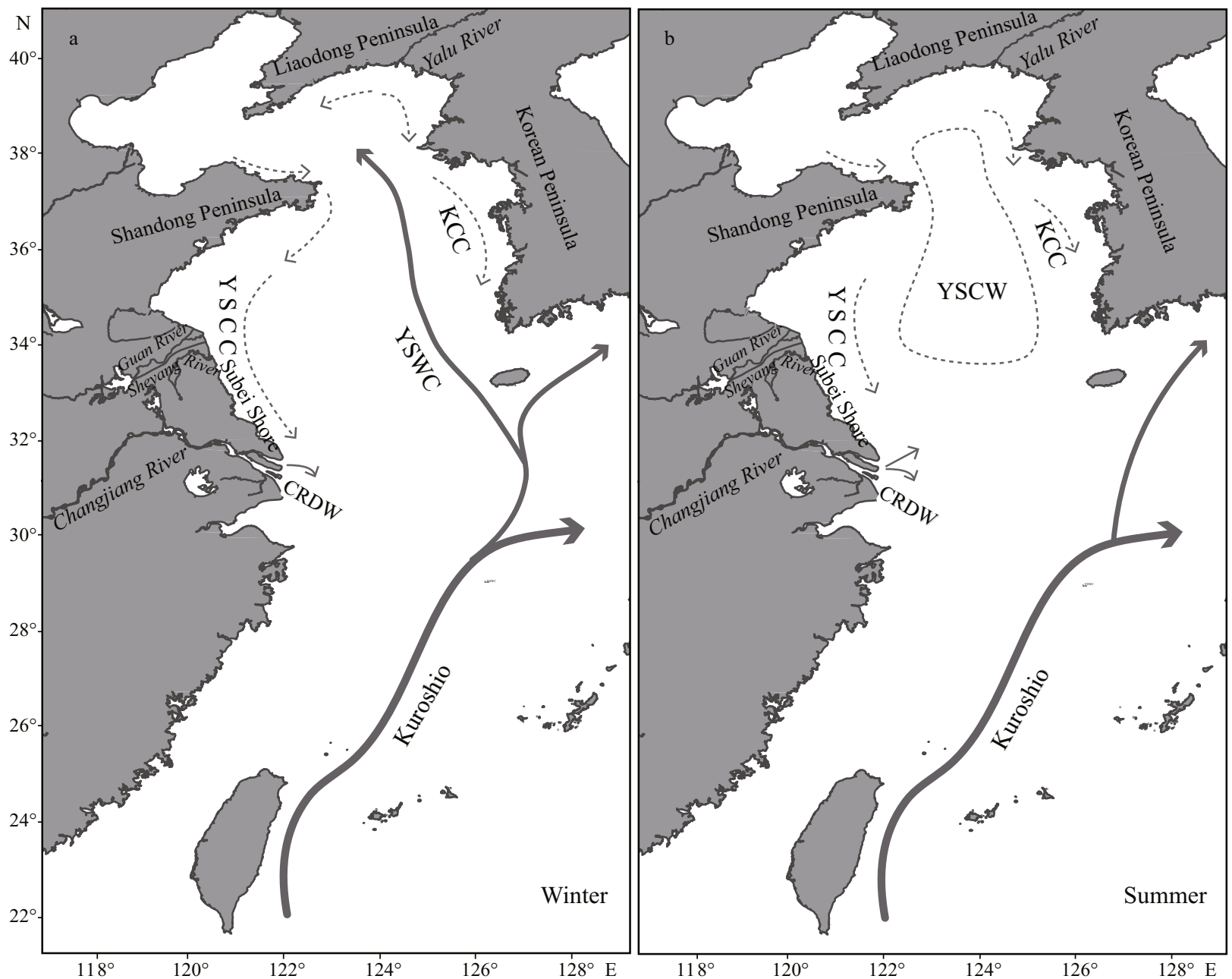

Fig.2 General hydrodynamic features of the Yellow Sea, redrawn from Su (1998) and Naimie et al. (2001)

a. circulation in winter; b. circulation in summer, including the Yellow Sea Coastal Current (YSCC), the Yellow Sea Warm Current (YSWC), the Korean Coastal Current (KCC), and the Changjiang River diluted water (CRDW).

usually represents the average surface condition and is not dated directly (Crosta and Koç, 2007). According to studies of modern sedimentation rates in the study area (Table 1), the rate is $0.1-1.0 \mathrm{~cm} / \mathrm{a}$ (centimeters per annum) in the YS and $0.6-6.0 \mathrm{~cm} / \mathrm{a}$ in the sea adjacent to the Changjiang River. Therefore, the top $2 \mathrm{~cm}$ of these box cores likely represent recent material, and modern hydrological parameters (sea temperature, salinity and nutrient conditions) were used for assisting the analysis of the top $2 \mathrm{~cm}$ sediment.

\subsection{Analysis of siliceous microfossils}

The top $2 \mathrm{~cm}$ surface sediment samples were pretreated to isolate siliceous microfossils (diatoms and silicoflagellates) following the methods in Renberg (1990) and Battarbee et al. (2001). Before processing, lyophilization was chosen to dry all of the sub-samples to avoid breaking the cell walls. The samples were treated with $10 \% \mathrm{HCl}$ (hydrochloric acid) overnight to remove carbonate. Then $30 \% \mathrm{H}_{2} \mathrm{O}_{2}$ (hydrogen peroxide) was added to remove organic matter, metal salts and oxides. The samples with a high proportion of clay were treated with ammonium hydroxide solution and washed repeatedly by suspending and dispersing the material in distilled water. Each time, the supernatant was decanted off after $3-5 \mathrm{~h}$ of deposition. Finally, the siliceous portions were floated by heavy liquid of zinc bromide (specific gravity 2.4). A $0.1-\mathrm{mL}$ volume of suspension was placed onto a cover-slip and dried, then mounted with Naphrax to make a permanent slide for each sample.

Species were identified and counted with an Olympus CX-31 polarization microscope in a brightfield at a magnification of $400 \times$ and $1000 \times$. The taxonomy and nomenclature were identified according to Chin et al. (1992), Cheng et al. (1996), Hasle and Syvertsen (1996) and Guo and Qian (2003). 
Table 1 Estimated sedimentation rates in the Yellow Sea (YS) in previous studies with sites corresponding to this study

\begin{tabular}{|c|c|c|c|c|}
\hline Location & Corresponding sites & Water depth (m) & Sedimentation rate $(\mathrm{cm} / \mathrm{a})$ & References \\
\hline Bohai Strait & $\mathrm{N} 1,2,5,6$ & $16-66$ & $0-0.2$ & Jiang et al., 2003 \\
\hline North of the northern YS & $\mathrm{N} 3,4,7,10,15,16$ & $18-40$ & $0.1-1.0$ & Li et al., 2002; Li et al., 2012 \\
\hline South of the northern YS & N9, 14, 23, 24 & $12-54$ & $0-0.1$ & Jiang et al., 2003 \\
\hline Central of the northern YS & $\mathrm{N} 8,12,13,17,18,20-22,28-31$ & $41-59$ & $0-0.2$ & Li et al., 2002 \\
\hline Chengshan Cape & $\mathrm{N} 25-27, \mathrm{~S} 1,1-2,1-3,1-4,1-5$ & $34-71$ & $0-0.1$ & Li et al., 2002; Hu et al., 2011 \\
\hline North of the southern YS & $\mathrm{S} 2-10,12-15,22-25$ & $19-75$ & $0.2-0.5$ & $\begin{array}{l}\text { Li et al., 2002; Hu et al., } \\
\text { 2011; Li et al., } 2012\end{array}$ \\
\hline Central of the southern YS & $\begin{array}{c}\mathrm{S} 11,16-21,26-29,31,37-41 \\
43-48,50-52,54-56,58-61\end{array}$ & $25-92$ & $0-0.2$ & $\begin{array}{l}\text { Li et al., 2002; Hu et al., } \\
\text { 2011; Li et al., } 2012\end{array}$ \\
\hline South of the southern YS & $\mathrm{S} 30,32-36,42,49,53$ & $11-21$ & $0-0.5$ & Li et al., 2002 \\
\hline $\begin{array}{c}\text { Nearshore of the } \\
\text { Changjiang River estuary }\end{array}$ & S57, 62-65, 69, 70, 75-77 & $11-48$ & $\begin{array}{c}6.0 \text { (maximum) } \\
1.0-3.0 \text { (most sites) }\end{array}$ & Li et al., 2012 \\
\hline $\begin{array}{c}\text { Offshore of the Changjiang } \\
\text { River estuary }\end{array}$ & S66-68, 71-74, 78-81 & $49-96$ & $0.6-1.8$ & Su and Huh, 2002 \\
\hline
\end{tabular}

The latest genus and species names were corrected against the "Algae Database" (http://www.algaebase. org, accessed December 2013). Diatoms and silicoflagellates were generally identified to species level. However, the genus Pleurosigma and Chaetoceros spores were not identified to species level because of their unclear features. Only two silicoflagellate species (Dictyocha messanensis and Distephanus speculum) were identified in the slides.

Abundances were counted and calculated according to Battarbee et al. (2001). Random fields of each slide were counted to obtain 300-600 cells for each sample. Fewer than 100 cells were identified at 16 sites, including N12, N30, N31, S5, S7, S1-2-S1-5, S19, S33, S38, S42, S56, S70 and S71 (Fig.1b, c); considering their extremely low cell concentrations, their absolute abundances $\left(D_{\text {abs }}\right)$ were considered approximate "0" values.

In the study area, siliceous microfossils appeared well preserved: several fragile species such as Coscinodiscus debilis and Coscinodiscus subtilis could be found as intact frustules. Paralia sulcata could often be seen in chains with over four cells. Five random slides were examined to estimate the ratio of intact frustules and/or skeletons at 400× according to the method of McQuoid and Hobson (2001). The ratios of intact frustules and/or skeletons on these five slides were calculated to be $53.2 \%$ $77.6 \%$

The $D_{\text {abs }}$ was calculated to represent the siliceous microfossils' total quantity as follows:

$$
D_{\text {abs }}=\frac{N \times V}{V_{1} \times W} \text { (unit: cells/g DW; DW means dry }
$$

sediment weight),

where $N$ is the total individuals counted for each sample, $V$ is the volume to which suspended diatoms were diluted, $V_{1}$ is the volume of aliquot dropped on slides, and $W$ is the dried weight of the sample.

The relative abundance for each taxon $\left(D_{\text {re }}\right)$ was calculated as a percentage based on the cell sums of each sample:

$$
D_{\text {re }}=\frac{N_{\text {sp }}}{N} \times 100 \% \text {, }
$$

where $N_{\text {sp }}$ is the sum of one taxon in each sample and $N$ is the total cells counted for each sample.

The Shannon-Wiener index $\left(H^{\prime}\right)$ (Shannon and Weaver, 1949) was calculated based on the species composition and their abundances:

$$
H^{\prime}=-\sum_{i=1}^{s} P_{i} \times \log _{2} P_{i},
$$

where $H^{\prime}$ is the Shannon-Wiener index, $S$ is the total number of diatoms and silicoflagellates, and $P_{i}$ is the proportion of each species in the sample.

The species richness index $(D)$ was calculated according to Margalef (1968) as follows:

$$
D=(S-1) \times \log _{2}(N),
$$

where $S$ is the number of species for each sample.

\subsection{Grain size analysis}

Grain sizes for all samples were examined automatically by a Mastersize 2000 Laser Particle Sizer to assess the sedimentary environment in the study area. Before measurement, the sediment samples were oxidized in $10 \% \mathrm{H}_{2} \mathrm{O}_{2}$ to remove 
organic matter and dispersed in a $0.05 \%\left(\mathrm{NaPO}_{3}\right)_{6}$ solution to isolate discrete particles. The grain sizes were classified into three groups (clay: $<4 \mu \mathrm{m}$; silt: 4-63 $\mu \mathrm{m}$; and sand: $>63 \mu \mathrm{m})$, according to Folk et al. (1970).

\subsection{Data analysis}

Out of 269 siliceous taxa identified, 29 taxa (including the silicoflagellate $D$. messanensis) with $\geq 0.5 \%$ individual proportion of the total cells were selected for statistical analysis. Because rare species with insufficient abundances were not statistically significant (Katoh, 1993), they were removed prior to analysis. A logarithmic transformation of $\log (x+1)$ was applied for the matrix data with $D_{\text {re }}$ of these 29 taxa at 97 sites to reduce the score and bias of species with extremely high abundance, which could mask the effect of low-abundant species (Field et al., 1982). A statistical examination of the $D_{\text {re }}$ data was processed using cluster analysis (software PRIMER 6). The Q mode Bray-Curtis cluster was chosen for producing distinct groups according to similarities higher than $50 \%$ (Fig.3a). The result of a two-way analysis of similarities (ANOSIM) indicated highly significant spatial differences (Global $R=0.746, P=0.01<0.05$ ) between these groups.

Correlations between the floral parameters $\left(D_{\text {abs }}, H^{\prime}\right.$ and $D$ ) and sediment grain size were analyzed using the software SPSS 20.0 (Statistical Product and Service Solutions) to evaluate the impacts of grain size on the preservation of microfossil flora. The correlations between indicative species and major environmental factors (water depth, temperature, salinity and nutrients) were analyzed using canonical correspondence analysis (CCA) in the statistical program CANOCO Version 4.5 (ter Braak and Smilauer, 2002). Environmental data obtained by our group from the open cruises of summer and autumn 2013 in the YS (data not published) were used to give a general picture of the environmental background of the YS.

\section{RESULT}

\subsection{Spatial distribution of abundance and species diversity}

In total, 267 diatom taxa and two silicoflagellate species (Dictyocha messanensis and Distephanus speculum) were identified among the 113 sampling sites (Appendix I). Temperate species dominated the diatom microfossils, but a few tropical species occurred (e.g., Coscinodiscus oculatus, Ditylum brightwellii), reflecting the temperate climatic regime of the study area with the impact of the YSWC. Marine species dominated the diatom microfossils, but a small proportion of freshwater species (e.g., Melosira islandica, Cyclotella comta) and a large number of brackish species (e.g., Cyclotella stylorum, Actinocyclus ehrenbergii) were identified at the sites near the Changjiang River mouth and in the coastal waters, respectively, indicating the impact of freshwater input.

The absolute abundance of diatoms and silicoflagellates ranged from $0.6 \times 10^{3}$ cells $/ \mathrm{g}$ DW to $646.9 \times 10^{3}$ cells $/ g$ DW in the study area, with higher values in the center of the northern YS (averaging at $241.3 \times 10^{3}$ cells $/ \mathrm{g}$ DW) and the area at approximately $32^{\circ}-33^{\circ} \mathrm{N}$ (averaging $43.3 \times 10^{3}$ cells $/ \mathrm{g} \mathrm{DW}$ ), and lower values in the transects at approximately $37.4^{\circ} \mathrm{N}$ (averaging $1.3 \times 10^{3}$ cells $/ \mathrm{g} \mathrm{DW}$ ) and $34^{\circ} \mathrm{N}$ (averaging $3.0 \times 10^{3}$ cells/g DW) (Fig.4a). The spatial pattern of the diversity index $\left(H^{\prime}\right)$ presented some differences from the absolute abundance, as higher $H^{\prime}$ values (5.1-5.3) occurred in the area adjacent to the Changjiang River mouth and lower values (1.1-2.9) occurred near the southern coast of the northern YS (Fig.4b).

\subsection{Geographic classification}

Although the diatoms and silicoflagellates showed a mixed spatial distribution at a few sites, most sites clearly fell into one of three groups based on the Q mode clustering analysis (Fig.3a). Their geographic features are described below (Fig.3b):

1) The sites in Group I were mainly distributed in the northern YS and the southern YS with water depths over $30 \mathrm{~m}$. Two sub-groups were identified in Group I by similarity analysis (Fig.3a, b). Group I (a) was widely distributed with dominant species Paralia sulcata (45.5\%), Thalassiosira eccentrica $(6.7 \%)$ and Coscinodiscus spp. (5.0\%) (Table 2). Group I (b) was scattered in the offshore areas of the southern YS, where the water depth was over $50 \mathrm{~m}$ (Fig.5b), with two dominant species, P. sulcata $(40.6 \%)$ and Podosira stelliger (33.5\%) (Table 2).

2) Only eight sites were classified into Group II and they were distributed near the southern coast of the northern YS (Fig.3a, b). $H^{\prime}$ in Group II was relatively lower than the other two groups (Table 2). $P$. stelliger $(44.1 \%)$ and $P$. sulcata $(11.3 \%)$ still dominated in Group II, while the proportion of $P$. sulcata was much lower than in Group I (Table 2). 

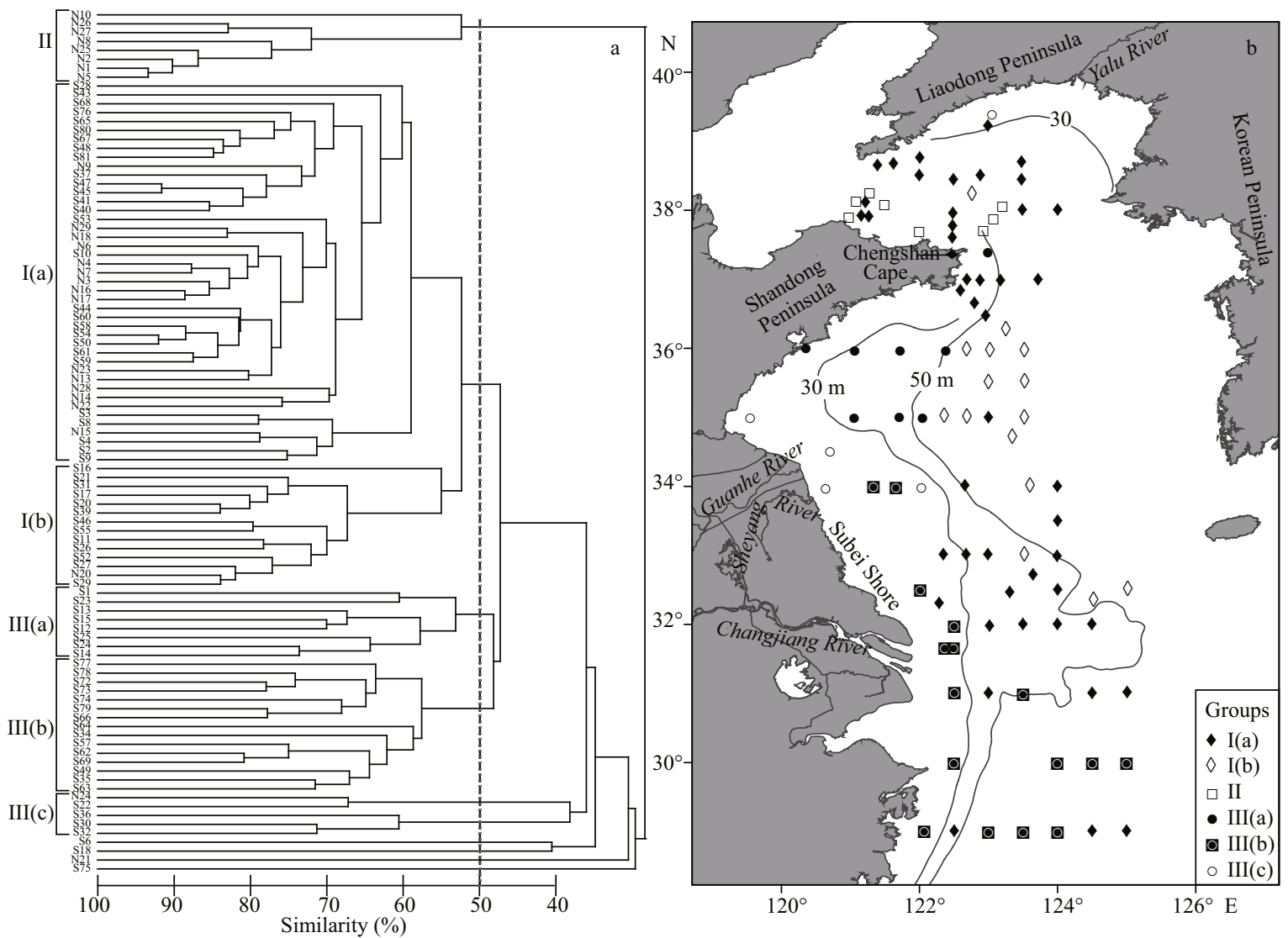

Fig.3 Q mode clustering analysis for classifying the groups of diatoms and silicoflagellates in the study area a. the dendrogram for Q mode clustering with a dashed line representing the $50 \%$ similarity; b. the geographical distribution of three groups with sub-groups.
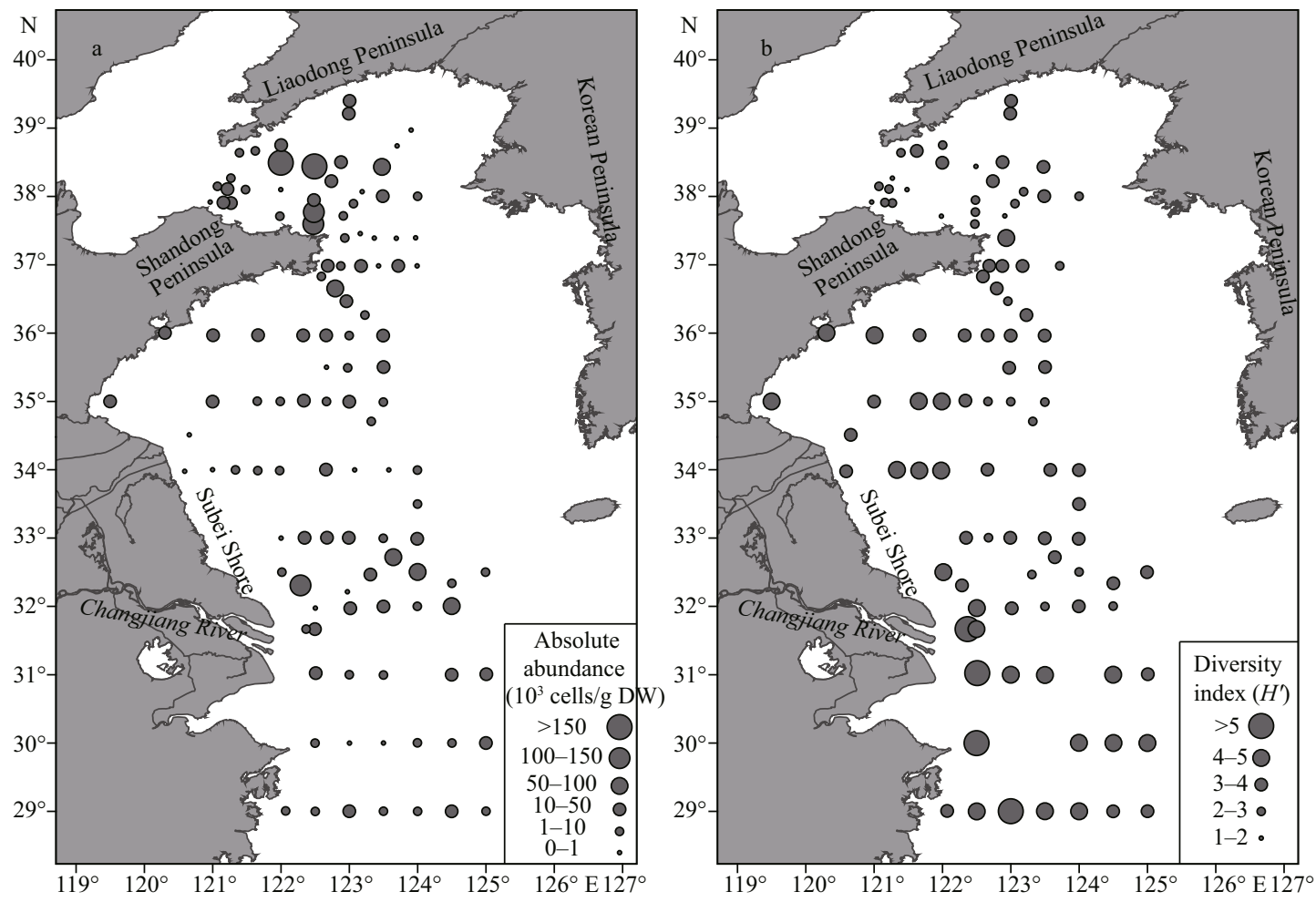

Fig.4 The spatial variations in absolute abundance and diversity index $\left(H^{\prime}\right)$ of diatoms and silicoflagellates in the study area a. absolute abundance; b. diversity index. 
Table 2 The absolute abundance, diversity index and dominant species in three groups with sub-groups

\begin{tabular}{|c|c|c|c|c|c|c|c|}
\hline \multirow{2}{*}{ Groups } & \multicolumn{2}{|c|}{ Absolute abundance $\left(10^{3}\right.$ cells/g DW) } & \multicolumn{2}{|c|}{ Diversity index- $H^{\prime}$} & \multirow{2}{*}{ Dominant species } & \multirow{2}{*}{ Range (\%) } & \multirow{2}{*}{ Average $(\%)$} \\
\hline & Range & Average & Range & Average & & & \\
\hline \multirow{3}{*}{$\mathrm{I}(\mathrm{a})$} & \multirow{3}{*}{$0.7-646.9$} & \multirow{3}{*}{39.9} & \multirow{3}{*}{$1.7-4.4$} & \multirow{3}{*}{3.2} & Paralia sulcata & $8.7-78.1$ & 45.5 \\
\hline & & & & & Thalassiosira eccentrica & $0.3-26.0$ & 6.7 \\
\hline & & & & & Coscinodiscus spp. & $0.5-9.7$ & 5.0 \\
\hline \multirow{2}{*}{$\mathrm{I}(\mathrm{b})$} & \multirow{2}{*}{$0.6-79.8$} & \multirow{2}{*}{16.7} & \multirow{2}{*}{$2.5-3.9$} & \multirow{2}{*}{3.3} & Paralia sulcata & $4.5-42.6$ & 40.6 \\
\hline & & & & & Podosira stelliger & $3.9-52.5$ & 33.5 \\
\hline \multirow{3}{*}{ II } & \multirow{3}{*}{$5.0-120.1$} & \multirow{3}{*}{47.2} & \multirow{3}{*}{$1.1-2.4$} & \multirow{3}{*}{1.9} & Podosira stelliger & $13.8-66.5$ & 44.1 \\
\hline & & & & & Actinocyclus ehrenbergii & $7.9-79.6$ & 35.6 \\
\hline & & & & & Paralia sulcata & $1.1-21.9$ & 11.3 \\
\hline \multirow{6}{*}{ III(a) } & \multirow{6}{*}{$1.8-18.1$} & \multirow{6}{*}{7.5} & \multirow{6}{*}{$3.6-4.4$} & \multirow{6}{*}{4.0} & Paralia sulcata & $6.5-25.7$ & 16.4 \\
\hline & & & & & Actinocyclus ehrenbergii & $1.9-35.4$ & 11.3 \\
\hline & & & & & Podosira stelliger & $4.1-16.8$ & 10.7 \\
\hline & & & & & Cyclotella stylorum & $0.5-19.0$ & 7.1 \\
\hline & & & & & Actinocyclus octonarius & $0.0-18.2$ & 6.7 \\
\hline & & & & & Trachyneis spp. & $0.9-8.9$ & 4.5 \\
\hline \multirow{5}{*}{$\mathrm{III}(\mathrm{b})$} & \multirow{5}{*}{$1.5-46.5$} & \multirow{5}{*}{17.5} & \multirow{5}{*}{$3.4-5.3$} & \multirow{5}{*}{4.6} & Cyclotella stylorum & $4.0-44.3$ & 21.1 \\
\hline & & & & & Coscinodiscus spp. & $7.3-10.8$ & 9.4 \\
\hline & & & & & Actinoptychus senarius & $0.5-18.1$ & 6.5 \\
\hline & & & & & Actinocyclus ehrenbergii & $1.8-11.6$ & 6.0 \\
\hline & & & & & Podosira stelliger & $0.5-7.7$ & 3.7 \\
\hline \multirow{5}{*}{$\mathrm{III}(\mathrm{c})$} & & & & & Coscinodiscus spp. & $5.0-67.8$ & 17.5 \\
\hline & & & & & Paralia sulcata & $2.7-26.4$ & 12.6 \\
\hline & $0.7-103.2$ & 21.7 & $3.0-4.4$ & 3.8 & Podosira stelliger & $1.4-30.8$ & 9.7 \\
\hline & & & & & Actinoptychus senarius & $1.6-20.8$ & 8.8 \\
\hline & & & & & Pleurosigma spp. & $0.6-7.0$ & 3.1 \\
\hline
\end{tabular}

Moreover, a large number of A. ehrenbergii (35.6\%) were present in Group II (Table 2).

3) The sites in Group III covered most of the coastal waters shallower than $30 \mathrm{~m}$ in the southern YS and most of the marine area adjacent to the Changjiang River mouth. Three sub-groups from north to south were also classified based on similarity analysis (Fig.3a, b). When compared with Groups I and II, the percentages of dominant $P$. sulcata $(12.6 \%-16.4 \%)$ and $P$. stelliger $(3.7 \%-10.7 \%)$ showed a significant decline in Group III, while brackish species, e.g., $C$. stylorum (7.1\%-21.1\%), increased distinctly, indicating the impact of freshwater input (Table 2).

\subsection{The spatial distribution of sediment grain size}

Six sediment types were discerned in the YS, including sandy mud, silt, sandy silt, muddy sand, silty sand and sand (Fig.5). Fine sediment (sandy mud) dominated in the central YS, while coarse sediment (silt and sand) mainly occurred in the offshore area of the Changjiang River mouth. In the northern YS, the sediments in the north were coarser than the sediment in the south, indicating the impact of input from the Yalu River. In addition, there were a few sporadic coarse sediments distributed in the southern coast of the YS.

\section{DISCUSSION}

Based on our results, the spatial distributions of siliceous microfossils in the YS were classified into three geographic groups: 1) a south-north geographic pattern in response to variations in sea temperature, 2) a coastal-offshore pattern following variation in salinity and 3) a large river mouth pattern resulting from the Changjiang River input. The environmental factors related to these patterns are discussed below, including nutrient levels, sedimentation rate, sea temperature, salinity, and water depth. 


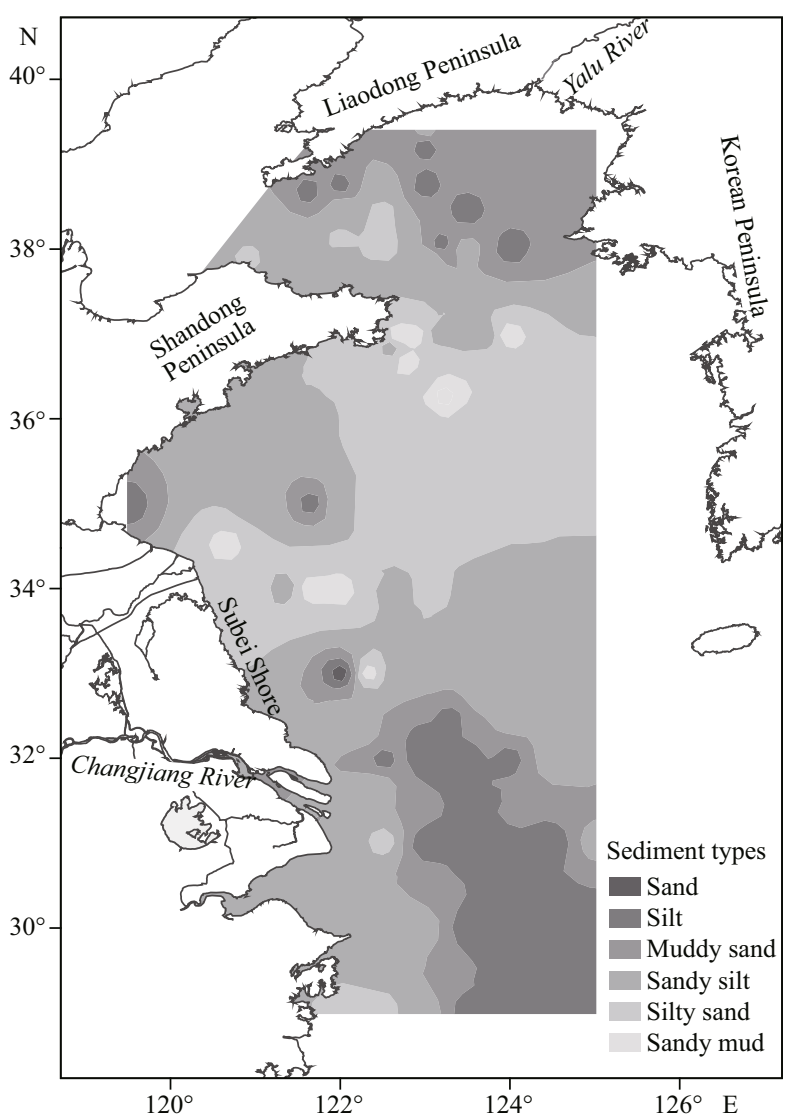

Fig.5 The spatial distribution of sediment types in the study area

\subsection{The impact of nutrient and sedimentary environment}

In general, nutrient levels play an important role in determining phytoplankton abundance in coastal and shelf waters (Cloern, 2001; Howarth and Marino, 2006). Over the last three decades, increased anthropogenic activities (e.g., agriculture, aquaculture and industrial activity) have led to a high nitrogen level along the coastline of the YS (Wang et al., 2003; Lin et al., 2005; Li et al., 2013b). Based on official monitoring data in the YS (SOA, 2009), dissolved inorganic nitrogen (DIN) in more than $50 \%$ of coastal areas exceeded $14 \mu \mathrm{mol} / \mathrm{L}$, which is the national standard of Level IV seawater quality in China. In comparison, the northern YS and the marine area adjacent to the Changjiang River were characterized by higher DIN concentrations than the open sea of the southern YS because of their semi-enclosed topographies and river inputs. In summer and autumn 2013, an in-situ survey in the YS showed that the distribution of DIN concentrations in the water column matched the historical observations (Fig.6a, b), with higher values in the northern YS and the marine area adjacent to the Changjiang River. In summer, the Changjiang River plume disperses to the north and east of the river mouth, and a branch of riverine tongue extends northward from $32^{\circ}-33^{\circ} \mathrm{N}$ to the tip of the Korean Peninsula, which supplies rich nutrients for phytoplankton growth (Riedlinger and Preller, 1995; Chang and Isobe, 2003). Consequently, the satellite chlorophyll $a$ concentrations in the northern YS also showed higher values than in the southern YS (Yamaguchi et al., 2012; Liu and Wang, 2013). These data are consistent with our finding that most sites with high microfossil abundance occur in the northern YS and the marine area adjacent to the Changjiang River mouth (Fig.4a).

However, not all sites in the northern YS and the marine area adjacent to the Changjiang River displayed high microfossil concentrations. For example, transects S2-7 and S69-74 showed very low abundances (Figs.1c, 3a). This might be related to the spatial variations in the sedimentary environment. Previous studies have indicated that the sedimentation rate and grain size can significantly influence the abundance of microfossils in the sediment by altering the processes of deposition and preservation (Crosta and Koç, 2007; Méléder et al., 2007). In the southern sea near the Changjiang River mouth, extremely high sedimentation rates (up to $6.0 \mathrm{~cm} / \mathrm{a}$ ) were found in previous studies (Table 1). Such high sedimentation rates can dilute the microfossil abundance in the sediment because of a fast burial process, leading to the very low microfossil abundances found locally in our study (Fig.4a). However, very low sedimentation rates $(0-0.1 \mathrm{~cm} / \mathrm{a})$ near the Chengshan Cape along the $37^{\circ} \mathrm{N}$ transect (Table 1 ) also corresponded to very low microfossil abundance (Fig.4a). The topography of Chengshan Cape causes the fastest local tidal current in the YS, with a maximum speed of $2 \mathrm{~m} / \mathrm{s}$ ( $\mathrm{Li}$ et al., 2013a). This current makes it difficult for the suspended particles, particularly the light siliceous cells, to settle in the sediment and results in the lowest microfossil abundance and $H^{\prime}$ in this region. Furthermore, according to the Pearson correlations between grain sizes and the total microfossil abundance, species richness, and $H^{\prime}$ indices, no significant correlation was found between grain size and microfossil abundance. However, the species richness and $H^{\prime}$ indices showed some significant correlations with fine grain size at some sites dominated by silty sand (Table 3 ). The results of the correlation analysis suggested that the grain size might not be a determining factor for the spatial 

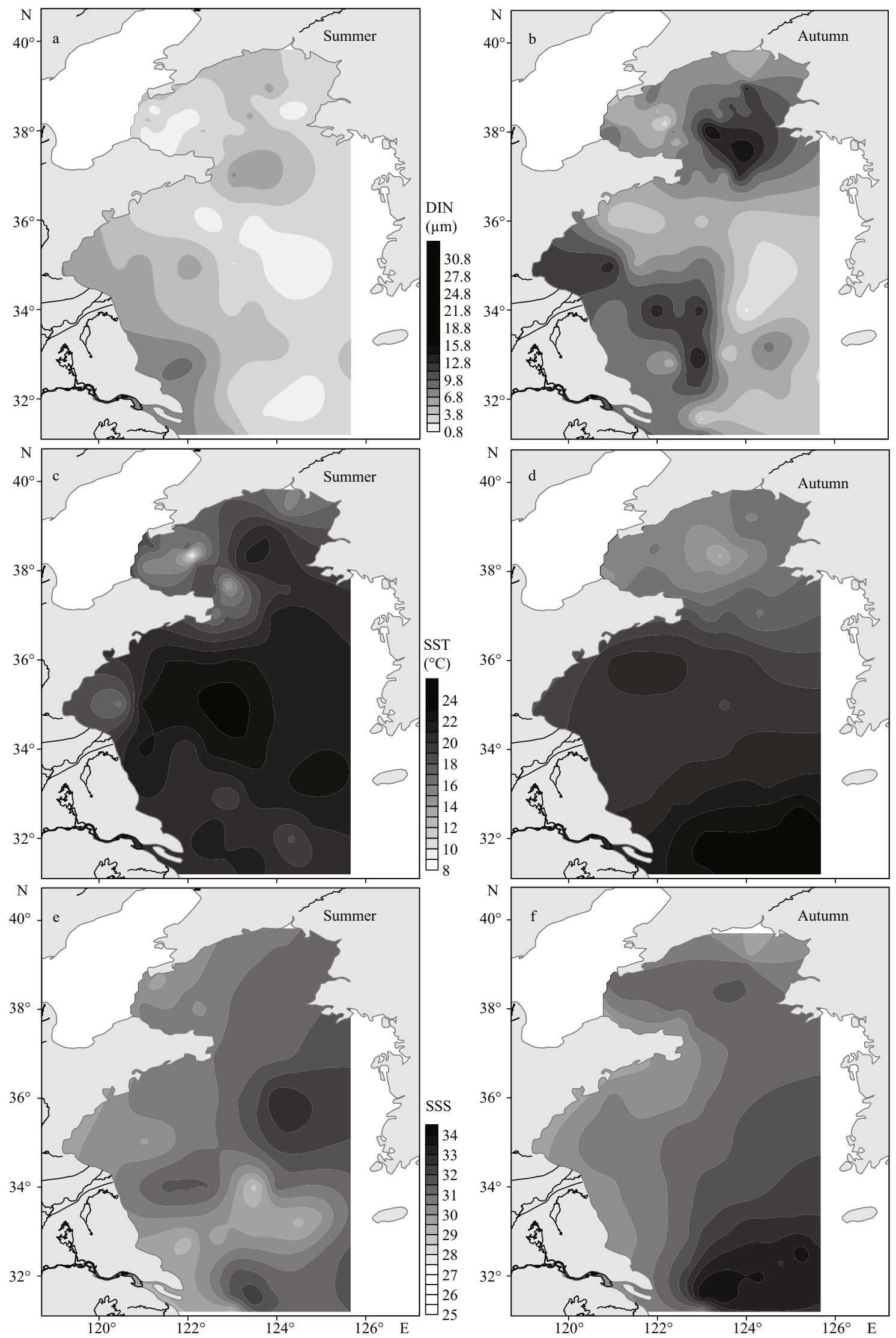

Fig.6 Spatial distribution of surface seawater parameters in summer and autumn 2013

DIN: dissolved inorganic nitrogen; SST: sea surface temperature; SSS: sea surface salinity 
Table 3 Correlations between biological parameters and grain sizes

\begin{tabular}{|c|c|c|c|c|}
\hline \multirow{2}{*}{ Item $^{\#}$} & & \multicolumn{3}{|c|}{ Grain size proportion } \\
\hline & & $<4 \mu \mathrm{m}$ & $4-63 \mu \mathrm{m}$ & $>63 \mu \mathrm{m}$ \\
\hline \multirow[t]{3}{*}{ Total } & $D_{\text {abs }}$ & -0.054 & 0.161 & -0.126 \\
\hline & $D$ & -0.012 & $-0.219^{*}$ & 0.189 \\
\hline & $H^{\prime}$ & 0.053 & -0.080 & -0.057 \\
\hline \multirow[t]{3}{*}{ Silt } & $D_{\text {abs }}$ & -0.296 & 0.212 & 0.231 \\
\hline & $D$ & $0.454^{*}$ & -0.285 & -0.401 \\
\hline & $H^{\prime}$ & 0.166 & 0.031 & -0.302 \\
\hline \multirow[t]{3}{*}{ Sandy silt } & $D_{\text {abs }}$ & -0.115 & 0.112 & -0.054 \\
\hline & $D$ & 0.030 & 0.047 & -0.050 \\
\hline & $H^{\prime}$ & 0.104 & 0.215 & -0.217 \\
\hline \multirow[t]{3}{*}{ Muddy sand } & $D_{\text {abs }}$ & -0.797 & -0.923 & 0.898 \\
\hline & $D$ & 0.766 & 0.847 & -0.834 \\
\hline & $H^{\prime}$ & 0.918 & 0.848 & -0.877 \\
\hline \multirow[t]{3}{*}{ Silty sand } & $D_{\text {abs }}$ & -0.323 & -0.220 & 0.260 \\
\hline & $D$ & $0.485^{*}$ & 0.105 & -0.221 \\
\hline & $H^{\prime}$ & $0.526^{*}$ & 0.277 & -0.362 \\
\hline
\end{tabular}

${ }^{\#} D_{\text {abs }}$ is the absolute abundances; $D$ is the species richness index; $H^{\prime}$ is the diversity index; the Pearson correlation was calculated for 95 sites as a whole and for groups of different sediment types separately (sedimentary parameters were missed in two sites). ${ }^{*}$ Correlation is significant at the 0.05 level (two-tailed).

pattern of microfossil abundance, but it could impact the species composition.

\subsection{The impact of sea temperature and salinity}

Temperature is an important determinant for the geographic range of species (McCarty, 2001). The YS covers a range of latitude from $29^{\circ} \mathrm{N}$ to $39.4^{\circ} \mathrm{N}$, with an obvious SST gradient from north to south. Under the control of latitudinal variation in solar radiation, the average annual SST in the northern YS is generally no more than $14^{\circ} \mathrm{C}$, but it can be $14-18^{\circ} \mathrm{C}$ in the southern YS, and can increase to $17-21^{\circ} \mathrm{C}$ near the Changjiang River mouth (Song et al., 2007). This temperature pattern was also reflected during our survey in summer and autumn 2013 (Fig.6c, d). As to the seasonal variations, the largest SST gradient occurred in winter, and could be up to $18^{\circ} \mathrm{C}$ between the northernmost (Liaodong Peninsula: $1-3^{\circ} \mathrm{C}$ ) and southernmost (near the Changjiang River mouth: 10$18^{\circ} \mathrm{C}$ ) areas (Lee and Chao, 2003). In addition, the hydrodynamic conditions in winter cause a significant temperature gradient between coastal and offshore areas (Lee and Chao, 2003). Under the impact of YSWC intrusion during winter, a northward thermal tongue enters into the central YS and can reach the northern YS (Fig.2a), resulting in higher temperatures in the central offshore area. In coastal waters, the current with lower temperature moves toward the southern coast as a compensation effect (Fig.2a).

Six species were selected among the dominant species to indicate the variations in temperature, salinity and nutrient based on their spatial patterns and ecological preferences described in previous literature (Fig.7). The warm-water species Coscinodiscus oculatus has been used to show a northward temperature decrease from the tropical waters in the Gulf of Thailand to the temperate East China Sea (e.g., Canh and Hao, 2001; Xie et al., 2007; Chen et al., 2010). In our study, this species displayed a strict SST-limitation in the YS, with a significant northward decrease in abundance, particularly north of $34^{\circ} \mathrm{N}$ (Fig.7a). The temperate species Dictyocha messanensis and Actinocyclus ehrenbergii had high abundances in colder waters in previous studies $\left(10^{\circ} \mathrm{C}\right)$ (Van Valkenburg and Norris, 1970; Hood et al., 1990). These two species in our study area showed much higher abundances in the northern YS than in the southern YS, indicating their preference for lower temperatures (Fig.7b, c). The correlation analysis between SST and these three species (C. oculatus, $D$. messanensis and $A$. ehrenbergii) further supported their temperature preference, as SST showed a positive correlation with $C$. oculatus and a negative correlation to D. messanensis and A. ehrenbergii (Fig.8).

The coastal-offshore pattern identified in this study may be in response to a salinity effect. In the northern YS, because of the freshwater input and the semienclosed topography, salinity is relatively lower, varying within a narrow gradient of 29-32 from coastal to offshore waters (Lee and Chao, 2003; Chen, 2009). This pattern was also reflected in our surveys during summer and autumn 2013 (Fig.6e, f). In the southern YS, the salinity is generally no more than 31 in shallow waters (depth $<30 \mathrm{~m}$ ), but can be $31-33$ in offshore waters (Lee and Chao, 2003; Chen, 2009). In contrast, salinity in the marine area adjacent to the Changjiang River is usually variable, with a wide range of 19-33.5 because of the impacts of freshwater input in summer and the intrusion of the East China Sea in winter (Chen, 2009). In our study, the brackish species Cyclotella stylorum had a close response to the salinity gradient, with a significant decrease in abundance where the water depth was deeper than $30 \mathrm{~m}$ (Fig.7d). Moreover, C. stylorum displayed a 

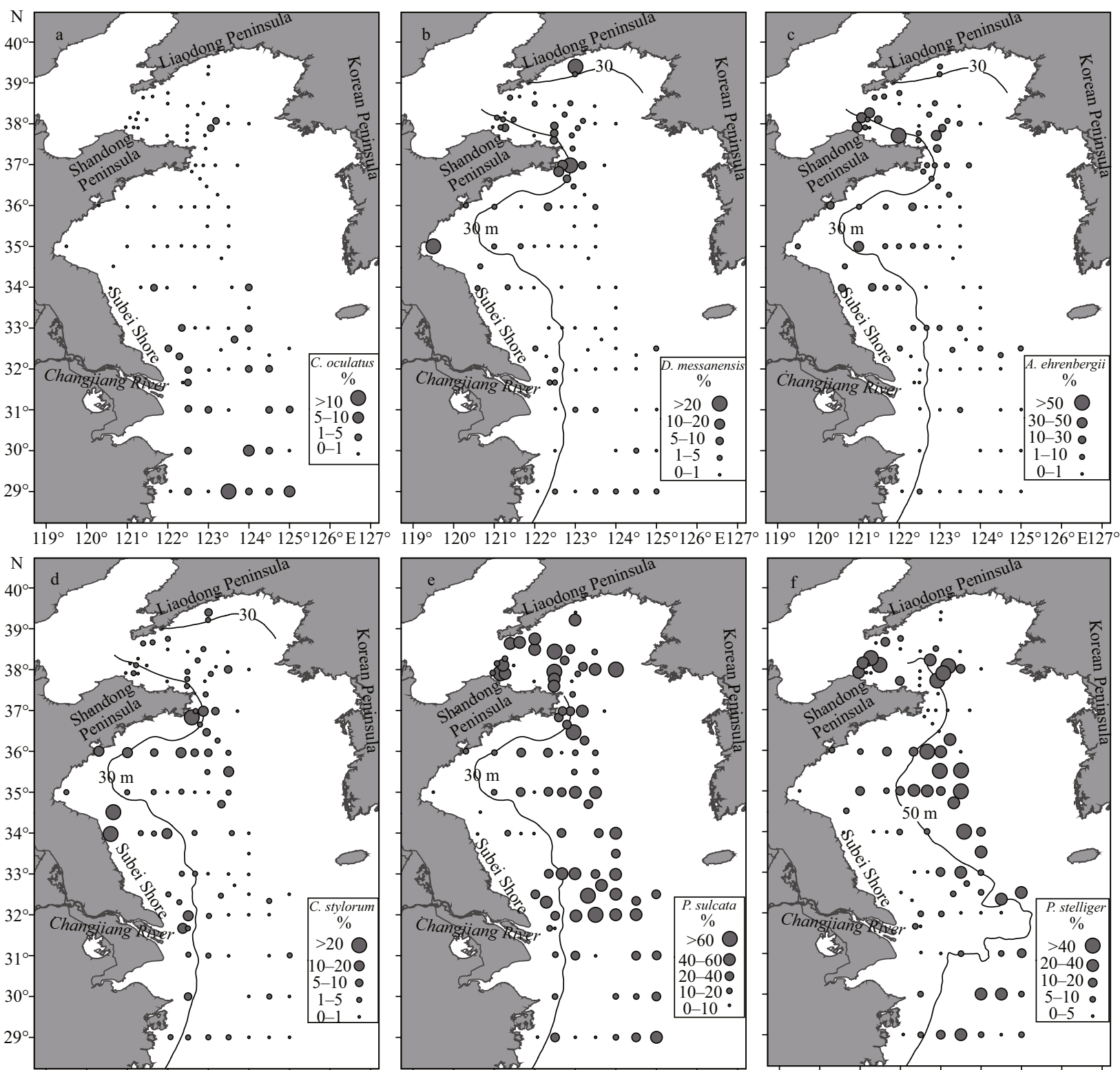

$119^{\circ} 120^{\circ} 121^{\circ} 122^{\circ} 123^{\circ} 124^{\circ} 125^{\circ} 126^{\circ} \mathrm{E} 127^{\circ}$

Fig.7 The spatial distributions of selected potential indicative species

a. Coscinodiscus oculatus; b. Dictyocha messanensis; c. Actinocyclus ehrenbergii; d. Cyclotella stylorum; e. Paralia sulcata; f. Podosira stelliger.

negative correlation with salinity and water depth, supporting its lower salinity preference (Fig.8). Microfossils D. messanensis and A. ehrenbergii were also considered as brackish-water-favoring species in previous studies (e.g., Rijstenbil, 1987; Sancetta, 1990; McQuoid and Hobson, 2001; Mirabdullayev et al., 2004). In the southern YS, the proportions of $D$. messanensis and A. ehrenbergii displayed a clear spatial decrease from coastal to offshore waters, particularly at water depths $>30 \mathrm{~m}$ (Fig. $7 \mathrm{~b}, \mathrm{c}$ ).

Paralia sulcata and Podosira stelliger were regarded as YSWC indicators in previous studies, and seemed to have a significant species-salinity relationship (Wang et al., 1985; Jiang, 1987). In our study, the two species displayed high abundances in the deep offshore waters, particularly at the water depth $>50 \mathrm{~m}$ (Fig.7e, f). P. sulcata showed a wide salinity tolerance in a previous study (Zong, 1997), and though it was generally described as a marine diatom (salinity range $=25-35$ ) (Hasle and Syvertsen, 1996), it has been recorded as tolerating a salinity range of 5 to 35 (Simonsen, 1962). Zong (1997) also found that $P$. sulcata was abundant during warmer periods and rich nutrient conditions. In this study, $P$. sulcata displayed a significantly positive correlation with DIN and salinity in autumn, and with SST in 


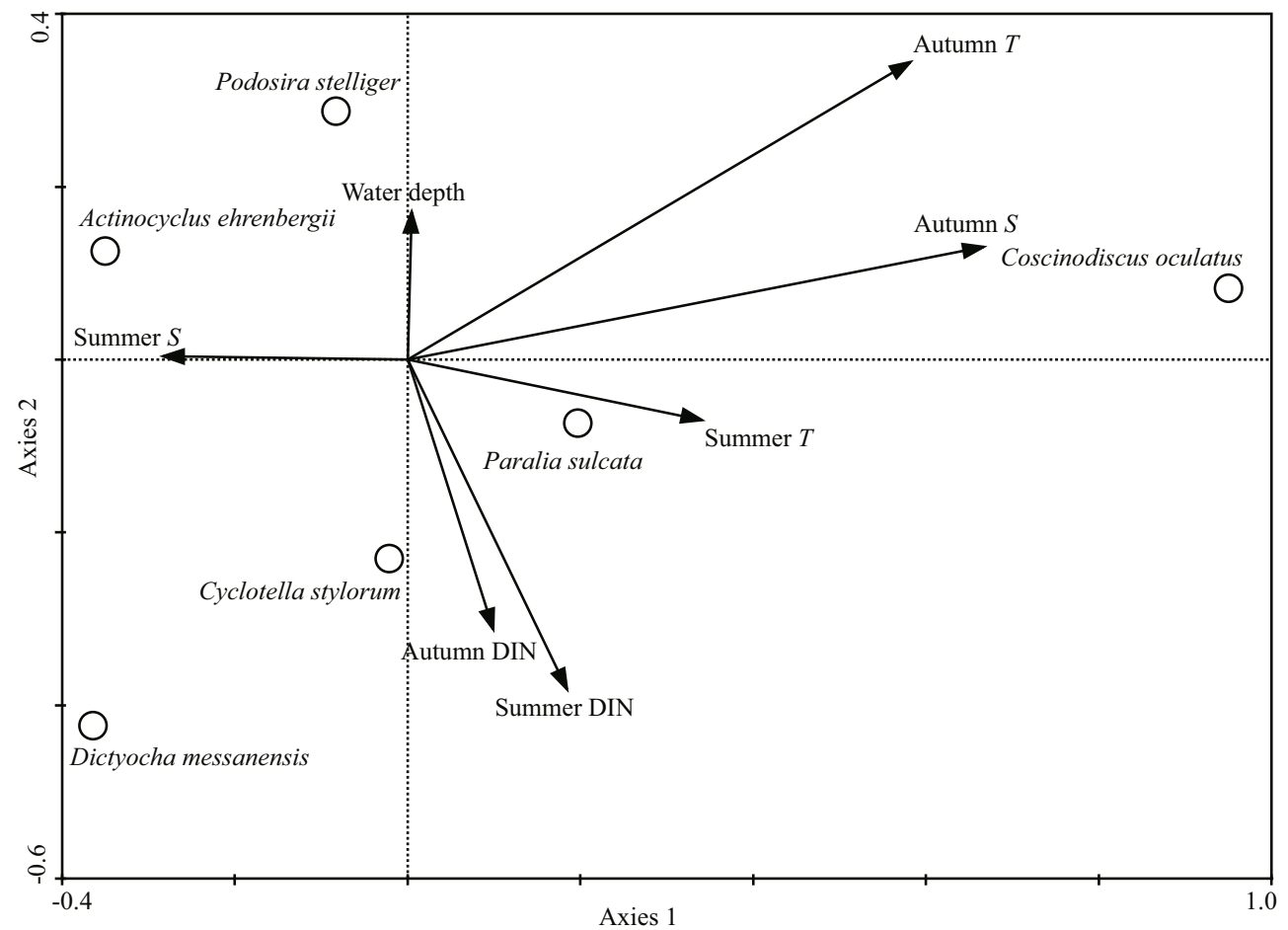

Fig.8 Biplot of six selected species in CCA ordination of axis 1 against axis 2 (Coscinodiscus oculatus; Dictyocha messanensis; Actinocyclus ehrenbergii; Cyclotella stylorum; Paralia sulcata; Podosira stelliger) and key environmental variables DIN: dissolved inorganic nitrogen; $T$ : temperature; $S$ : salinity.

summer. $P$. stelliger only showed a significantly positive correlation with water depth and summer salinity (Fig.8). These results were consistent with the study by Zong (1997), as DIN can significantly impact the abundance of $P$. sulcata, although this species prefers a relatively higher temperature and salinity. It appears that $P$. stelliger might be a better indicator for the YSWC than P. sulcata.

\subsection{The impact of river input}

In this study, Group III in the geographic distribution-further subdivided into sub-groups III(a), III(b), and III(c) - showed that a large river input can significantly impact species diversity and abundance by providing a unique habitat. The microfossil Group III(b) was found near the Changjiang River mouth (Fig.3b) expanded northward to the marine region of $34^{\circ} \mathrm{N}$ and eastward to $125^{\circ} \mathrm{E}$, which basically matched the pathway of the Changiiang River diluted water simulated by numerical modeling (Chang and Isobe, 2003). Groups III(a) and III(c) covered most coastal waters shallower than $30 \mathrm{~m}$ in the southern YS, where there are two major rivers (Guan River and Sheyang River) and a few small rivers emptying into the sea (Fig.3b).

When compared with the other two groups, Group
III was characterized by the highest diversity but relatively lower abundances (Table 2). Because the sediment and freshwater discharges from rivers decrease the salinity and increase the nutrients, brackish planktonic organisms have evolved a tolerance for intermediate salinities or salinity fluctuations, which can increase the species diversity, particularly in estuaries (Cortelezzi et al., 2007; Quinlan and Phlips, 2007; Muylaert et al., 2009). Meanwhile, there is a balance between rich nutrients and high sedimentation rates for the abundance of microfossils in the sediment. As discussed in Section 5.1, rich nutrients promote phytoplankton growth and lead to a high biomass, while high sedimentation rates can increase the burial rate of microfossils and yield volumetrically low biomass.

\section{CONCLUSION}

The spatial distributions of siliceous microfossils in the surface sediments of the Yellow Sea correspond with variations in the ambient environment, with multiple factors displaying integrative impacts on microfossil abundance and diversity. Both temperature and salinity closely correlate to species diversity. Very high or low sedimentation rates can significantly reduce the microfossil abundance in surface 
sediments. The impact of the Changjiang River on the adjacent sea was substantial and unique; therefore, the microfossil pattern in this region should be considered separately and in more detail in a future study. The 30-m and 50-m isobaths separating the occurrence patterns between coastal and offshore microfossils were consistent with previous observations in the Yellow Sea. This study provides a background for understanding the multiple local factors influencing environmental activity, which will be valuable for future reconstruction of the long-term paleo-environment in the Yellow Sea when using sediment cores. Further quantitative research should be strengthened to prove the identified factors affecting the microfossil distribution.

\section{ACKNOWLEDGMENT}

We appreciate the journal editors and unknown reviewers for their hard work and valuable comments on the manuscript. Our sincere gratitude is also addressed to our colleagues who supplied the environment data used in this work.

\section{References}

Battarbee R W, Jones V J, Flower R J, Cameron N G, Bennion H, Carvalho L, Juggins S. 2001. Diatoms. In: Smol J P, Birks H J B, Last W M, Bradley R S, Alverson K eds. Tracking Environmental Change Using Lake Sediments. Kluwer Academic Publishers, Dordrecht. p.155-203.

Berglund B E, Sandgren P, Barnekow L, Hannon G, Jiang H, Skog G, Yu S Y. 2005. Early Holocene history of the Baltic Sea, as reflected in coastal sediments in Blekinge, southeastern Sweden. Quat. Int., 130(1): 111-139.

Beyens L, Denys L. 1982. Problems in diatom analysis of deposits: allochthonous valves and fragmentation. Geol. Mijnbouw, 61: 159-162.

Canh N T, Hao V M. 2001. Distribution, abundance and species composition of phytoplankton in the Vietnamese waters. In: Proceedings of the SEAFDEC Seminar on Fishery Resources in the South China Sea, Area IV: Vietnamese Waters. Southeast Asian Fisheries Development Center, Bangkok. p.265-291.

Chang P H, Isobe A. 2003. A numerical study on the Changjiang diluted water in the Yellow and East China Seas. $J$. Geophys. Res., 108(C9): CiteID3 299.

Chen B H, Xu Z H, Zhou Q L, Chen C P, Gao Y H, Yang S Y, Ji W D. 2010. Long-term changes of phytoplankton community in Xiagu waters of Xiamen, China. Acta Oceanolog. Sin., 29(6): 104-114.

Chen C T A. 2009. Chemical and physical fronts in the Bohai, Yellow and East China seas. J. Mar. Syst., 78(3): 394-410.

Cheng Z D, Gao Y H, Dickman M. 1996. Colour Plates of the Diatoms. China Ocean Press, Beijing. 120p.

Chin T G, Cheng Z D, Liu S C, Ma J X. 1992. Marine Benthic Diatoms from China. China Ocean Press, Beijing. 434p. (in Chinese)
Cloern J E. 2001. Our evolving conceptual model of the coastal eutrophication problem. Mar. Ecol. Prog. Ser., 210: 223 253.

Cortelezzi A, Capítulo A R, Boccardi L, Arocena R. 2007. Benthic assemblages of a temperate estuarine system in South America: transition from a freshwater to an estuarine zone. J. Mar. Syst., 68(3-4): 569-580.

Crosta X, Koç N. 2007. Diatoms: from micropaleontology to isotope geochemistry. In: Calvert S E, Pedersen T F eds. Developments in Marine Geology. Elsevier. p.327-369.

Dawes C J. 1998. Marine Botany. $2^{\text {nd }}$ edn. John Wiley \& Sons, Inc., New York. 484p.

Du X N, Liu G X. 2009. Community structure of netphytoplankton in the northern Huanghai Sea in the winter of 2006. Acta Oceanolog. Sin., 31(5): 132-147. (in Chinese with English abstract)

Field J G, Clarke K R, Warwick R M. 1982. A practical strategy for analysing multispecies distribution patterns. Mar. Ecol. Prog. Ser., 8: 37-52.

Folk R L, Andrews P B, Lewis D W. 1970. Detrital sedimentary rock classification and nomenclature for use in New Zealand. N. Z. J. Geol. Geophys., 13(4): 937-968.

Guo X W, Zhang Y S, Zhang F J, Cao Q Y. 2010. Characteristics and flux of settling particulate matter in neritic waters: the southern Yellow Sea and the East China Sea. Deep Sea Res. Part II, 57(11-12): 1 058-1 063.

Guo Y J, Qian S B. 2003. Marine Bacillariophyta Centricae Flora China Sea. Science Press, Beijing. 493p. (in Chinese)

Hasle G R, Syvertsen E E. 1996. Marine diatoms. In: Tomas C $\mathrm{R}$ ed. Identifying Marine Diatoms and Dinoflagellates. Academic Press, San Diego. p.5-386.

Hood R R, Abbott M R, Huyer A, Kosro P M. 1990. Surface patterns in temperature, flow, phytoplankton biomass, and species composition in the coastal transition zone off northern California. J. Geophys. Res., 95(C10): 18 08118094.

Howarth R W, Marino R. 2006. Nitrogen as the limiting nutrient for eutrophication in coastal marine ecosystems: evolving views over three decades. Limnol. Oceanogr., 51(1part2): 364-376.

Hu B Q, Li G G, Li J, Yang M, Wang L B, Bu R Y. 2011. Spatial variability of the ${ }^{210} \mathrm{~Pb}$ sedimentation rates in the Bohai and Huanghai Seas and its influencing factors. Acta Oceanolog. Sin., 33(6): 125-133. (in Chinese with English abstract)

Jiang D H, Gao S, Li F Y. 2003. Numerical calculations of modern deposition rates for the Bohai Strait region. Mar. Sci., 27(3): 32-35. (in Chinese with English abstract)

Jiang H. 1987. Diatoms in surface sediments in coastal China seas. Acta Oceanolog. Sin., 9(6): 735-743. (in Chinese with English abstract)

Katoh K. 1993. Deletion of less-abundant species from ecological data. Diatom, 8: 1-5.

Lee H J, Chao S Y. 2003. A climatological description of circulation in and around the East China Sea. Deep Sea Res. II, 50(6-7): 1 065-1 084.

Li F Y, Gao S, Jia J J, Zhao Y Y. 2002. Contemporary deposition rates of fine-grained sediment in the Bohai and Yellow Seas. Oceanolog. Et Limnol. Sin., 33(4): 364-369. (in Chinese with English abstract)

Li J, Hu B Q, Dou Y G, Zhao J T, Li G G. 2012. Modern sedimentation rate, budget and supply of the muddy 
deposits in the East China Seas. Geological Review, 58(4): 745-756. (in Chinese with English abstract)

Li Q J, Zhou L M, Wu KJ, Li J K, Li Z B, Han L S. 2013a. Tidal stream energy assessment to Chengshantou. Tansactions of Oceanology and Liminology, (3): 10-18. (in Chinese with English abstract)

Li Y W, Hu Y Y, Chen S M. 2013b. Distribution and influence factors of nutrients in the North Yellow Sea in summer and autumn. China Environmental Science, 33(6): 1060 1 067. (in Chinese with English abstract)

Lin C, Ning X, Su J, Lin Y, Xu B. 2005. Environmental changes and the responses of the ecosystems of the Yellow Sea during 1976-2000. J. Mar. Syst., 55(3-4): 223-234.

Liu D Y, Wang Y Q. 2013. Trends of satellite derived chlorophyll- $a$ (1997-2011) in the Bohai and Yellow Seas, China: effects of bathymetry on seasonal and inter-annual patterns. Prog. Oceanogr., 116: 154-166.

Liu S M, Zhang J, Chen S Z, Chen H T, Hong G H, Wei H, Wu Q M. 2003. Inventory of nutrient compounds in the Yellow Sea. Cont. Shelf Res., 23(11-13): 1 161-1 174.

Margalef R. 1968. Perspectives in Ecological Theory. University of Chicago Press, Chicago.

McCarty J P. 2001. Ecological consequences of recent climate change. Conserv. Biol., 15(2): 320-331.

McQuoid M R, Hobson L A. 2001. A Holocene record of diatom and silicoflagellate microfossils in sediments of Saanich Inlet, ODP Leg 169S. Mar. Geol., 174(1-4): 111123.

Méléder V, Rincé Y, Barillé L, Gaudin P, Rosa P. 2007. Spatiotemporal changes in microphytobenthos assemblages in a macrotidal flat (Bourgneuf Bay, France). J. Phycol., 43(6): 1 177-1 190.

Mirabdullayev I M, Joldasova I M, Mustafaeva Z A, Kazakhbaev S, Lyubimova S A, Tashmukhamedov B A. 2004. Succession of the ecosystems of the Aral Sea during its transition from oligohaline to polyhaline water body. $J$. Mar. Syst., 47(1-4): 101-107.

Muylaert K, Sabbe K, Vyverman W. 2009. Changes in phytoplankton diversity and community composition along the salinity gradient of the Schelde estuary (Belgium/The Netherlands). Estuarine Coastal Shelf Sci., 82(2): 335-340.

Naimie C E, Blain C A, Lynch D R. 2001. Seasonal mean circulation in the Yellow Sea- a model-generated climatology. Cont. Shelf Res., 21(6-7): 667-695.

Quinlan E L, Phlips E J. 2007. Phytoplankton assemblages across the marine to low-salinity transition zone in a blackwater dominated estuary. J. Plankton Res., 29(5): 401-416.

Renberg I. 1990. A procedure for preparing large sets of diatom slides from sediment cores. J. Paleolimnol., 4(1): 87-90.

Riedlinger S, Preller R. 1995. Validation test report for the Yellow Sea shallow water analysis and forecast system. Draft NRL Report, Stennis Space Center, MI.

Rijstenbil J. 1987. Phytoplankton composition of stagnant and tidal ecosystems in relation to salinity, nutrients, light and turbulence. Neth. J. Sea Res., 21(2): 113-123.

Sancetta C. 1990. Seasonal occurrence of silicoflagellate morphologies in different environments of the eastern Pacific Ocean. Mar. Micropaleontol., 16(3-4): 285-291.

Shannon C E, Weaver W. 1949. The Mathematical Theory of
Communication. University of Illinois Press, Urbana.

Simonsen R. 1962. Untersuchungen zur systematik und ökologie der bodendiatomeen der westlichen ostsee. Internationale Revue der Gesamten Hydrobiologie Systematische Beihefte Nr. 1. Akademie-Verlag, Berlin.

Smol J P, Stoermer E F. 2010. Applications and uses of diatoms: prologue. In: Smol J P, Stoermer E F eds. The Diatoms: Applications for the Environmental and Earth Sciences. $2^{\text {nd }}$ edn. Cambridge University Press, New York. p.3-7.

SOA (State Oceanic Administration People's Republic of China). 2009. Marine Environment Quality Status of the National Seawaters, http://www.soa.gov.cn/. Accessed on 2014-12-10.

Song D H, Yu H M, Bao X W. 2007. Analysis of the interannual variability of the eastern China seas and its adjacent seas surface temperature. Periodical of Ocean University of China, 37(Sup.): 21-28. (in Chinese with English abstract)

$\mathrm{Su} \mathrm{C}$ C, Huh C A. 2002. ${ }^{210} \mathrm{~Pb},{ }^{137} \mathrm{Cs}$ and ${ }^{239,}{ }^{240} \mathrm{Pu}$ in East China Sea sediments: sources, pathways and budgets of sediments and radionuclides. Mar. Geol., 183(1-4): 163 178.

Su J L. 1998. Circulation dynamics of the China Seas north of 180 N. In: Robinson A R, Brink K H eds. The Sea. John Wiley \& Sons Inc., New York. p.483-505.

ter Braak C J F, Smilauer P. 2002. Canoco for Windows version 4.5. Biometrics-plant research international, Wageningen, Netherlands.

Van Valkenburg S D, Norris R E. 1970. The growth and morphology of the silicoflagellate Dictyocha fubula Ehrenberg in culture. J. Phycol., 6(1): 48-54.

Wang B D, Wang X L, Zhan R. 2003. Nutrient conditions in the Yellow Sea and the East China Sea. Estuarine Coastal Shelf Sci., 58(1): 127-136.

Wang K F, Jiang H, Zhang Y L, Wang Y J, Xu J S. 1985. Environmental discussion on distribution of the diatom in the surface sediments of the Huanghai Sea. Oceanolog. et Limnologia Sin., 16(5): 400-407. (in Chinese with English abstract)

Weckström K. 2006. Assessing recent eutrophication in coastal waters of the Gulf of Finland (Baltic Sea) using subfossil diatoms. J. Paleolimnol., 35(3): 571-592.

Xie W L, Chen C P, Gao Y H. 2007. Diatom community in sea waters between middle-north of Taiwan Strait and Nanji Archipelago in winter, 2005. Journal of Oceanography in Taiwan Strait, 26(3): 370-379. (in Chinese with English abstract)

Yamada S S, D'Elia C F. 1984. Silicic acid regeneration from esturaine sediment cores. Mar. Ecol. Prog. Ser., 18(1): 113-118.

Yamaguchi H, Kim H C, Son Y B, Kim S W, Okamura K, Kiyomoto Y, Ishizaka J. 2012. Seasonal and summer interannual variations of SeaWiFS chlorophyll $a$ in the Yellow Sea and East China Sea. Prog. Oceanogr., 105: 22-29.

Yu J L, Li R X. 1993. The study on the phytoplankton ecology in the Bohai and Yellow Seas. Advances in Marine Science, (3): 52-59. (in Chinese with English abstract)

Zong Y Q. 1997. Implications of Paralia sulcata abundance in Scottish isolation basins. Diatom Research, 12(1): 125150 . 